\title{
A study of sequence stratigraphy of the Early Cretaceous coal- bearing series in the southeastern Songliao Basin, NE China
}

\author{
Kai Shao ${ }^{1,2,3} \cdot$ Longyi Shao $^{2}$ (1) Dongmin $\mathrm{Ma}^{1} \cdot$ Dongdong Wang ${ }^{2,4}$. \\ Shuai Wang $^{2} \cdot$ Di Gao ${ }^{2,5}$
}

Received: 11 August 2019/Revised: 5 June 2020/Accepted: 11 June 2020/Published online: 17 July 2020

(C) The Author(s) 2020

\begin{abstract}
The Early Cretaceous is an important coal accumulation period in China. Abundant coal resources were formed in the southeastern margin of Songliao Basin. Sequence stratigraphy and coal accumulation of the Early Cretaceous in the southeastern margin of Songliao Basin have been studied on the basis of extensive outcrop and borehole data. Based on regional unconformity, basal erosional surfaces of incised valley fills, and abrupt depositional facies-reversal surface, six sequence boundaries have been identified, which subdivide the Early Cretaceous coal-bearing series into 5 third-order sequences. Sequence I corresponds to Huoshiling Formation, sequences II and III correspond to member I and member II of Shahezi Formation. Sequences IV and V correspond to member I and member II of Yingcheng Formation. Sequence I developed at the initial subsiding stage, sequence II and III developed during the stable subsiding stage, while sequence IV and V developed during the basin shrinkage stage. The major coal seams were developed in the sequence II and III, which ensured the relative balance between the increase rate of the accommodation space and the rate of peat accumulation for a longer period, thus forming a thick coal seam.
\end{abstract}

Keywords Songliao Basin $\cdot$ Sequence stratigraphy $\cdot$ Depositional system $\cdot$ Coal accumulation

Longyi Shao

ShaoL@cumtb.edu.cn

1 College of Resources and Environments, Xi' an University of Science and Technology, Xi' an 710054, Shaanxi, China

2 State Key Laboratory of Coal Resources and Safe Mining and College of Geoscience and Surveying Engineering, China University of Mining and Technology (Beijing), Beijing 10008, China

3 Shannxi Coalbed Methane Development Company Limited, Xi' an 710119, Shaanxi, China

4 College of Geological Science and Engineering, Shandong University of Science and Technology, Qingdao 266590, Shandong, China

5 College of Resources and Environments, Henan Polytechnic University, Jiaozuo 454000, Henan, China

\section{Introduction}

Songliao Basin is an important sedimentary basin in China, filled with the Cretaceous strata which contain not only abundant petroleum resources but also abundant coal resources ( $\mathrm{Li}$ 1988; Gao and Cai 1997; Wang et al. $2007,2013)$. It is located between $119^{\circ} 40^{\prime} \mathrm{E}$ to $128^{\circ} 24^{\prime} \mathrm{E}$, and $42^{\circ} 25^{\prime} \mathrm{N}$ to $49^{\circ} 23^{\prime} \mathrm{N}$, and covers roughly $260,000 \mathrm{~km}^{2}$ in Heilongjiang, Jilin, and Liaoning Provinces. Much research has been done on the tectonic evolution (Liu et al. 2011; Wang et al. 2013) and the sequences stratigraphy of Songliao Basin in relation with the oil exploration (Guo et al. 2004; Wang et al. 2013). Although abundant coal resources were developed in the Early Cretaceous strata of this basin, the relationships between the sequence stratigraphic framework and coal accumulation of this basin have not been well studied (Shao et al. 2014). Abundant coal resources developed in the southeastern margin of the Songliao Basin in Jilin Province have been mined for some decades (Han and Yang 1980), but the coal accumulation 
patterns were still not clearly recognized. The Yingcheng, Changchun and Liufangzi sub-basins, located in the southeastern margin of Songliao Basin in Jilin Province, were found with the Early Cretaceous coals, which provide opportunity to study depositional facies and sequence stratigraphic framework of the Early Cretaceous coalbearing series, and the coal accumulation patterns can be understood better through the study in these sub-basins.

Sequence stratigraphy has been used successfully in passive continental margin environments (Vail et al. 1977; Mitchum et al. 1977; Posamentier and Vail 1988; Van Wagoner et al. 1990; Catuneanu et al. 2009) and rifted lacustrine basins (Shanley and McCabe 1994; Lin et al. 2001; Feng et al. 2013a, b). In lacustrine basins, the paleotectonics and paleoclimates play an important role in sequence development, as opposed to the global sea level changes in the marine basins (Ravnas and Steel 1998; Strecker et al. 1999; Zecchin et al. 2006; Martins-Neto and Catuneanu 2010; Feng et al. 2013a, b; Li et al. 2018a, b; Wang et al. 2019). Olsen (1990) distinguished Richmondtype, Newark-type, and Fundy-type lacustrine depositional models. Carroll and Bohacs (1999) proposed three ancient lake types corresponding to 3 lacustrine facies associations, based on the balance between rates of potential accommodation and sediment + water supply. Since 1990s, a great number of coal geologists also regard sequence stratigraphy as a useful tool for analyzing the origin, form, thickness, distribution, and quality of coal seams in a sequence stratigraphic framework (Bohacs and Suter 1997; Holz et al. 2002; Shao et al. 2003; Gibling et al. 2004; Fielding et al. 2007; Jerrett et al. 2011; Wang et al. 2019). The thick coals could be considered as an isochronous surface in the coal-bearing series and often occur near the maximum flooding surface (Diessel 1992, 2007; Flint et al. 1995; Shao et al. 2011; Wang et al. 2020), which depends on the balance between the rates of accommodation and peat accumulation (Bohacs and Suter 1997). In intra-continental rift coal-bearing basin, coal seams exhibit poor stability with only local areas possessing great thickness (Li et al. 2018b; Wang et al. 2019). These theories and models need to be developed and improved in the coalbearing series of continental rift basins. How tectonics and accommodation affect the spatial configuration of depositional facies and coal accumulation in the Songliao Basin is a key research object.

A great deal of researches have been conducted on the stratigraphic subdivision and sub-correlation as well as depositional models of the Cretaceous across the entire Songliao Basin based on palynological data (Mi et al. 2010; Liu et al. 2011; Wang et al. 2016; Li et al. 2018a; Sun et al. 2019), tectonic evolution (Feng et al. 2013b; Wang et al. 2011; Wang et al. 2016), depositional environments (Liu et al. 2011; Feng et al. 2013b), sequence stratigraphic framework (Hu et al. 2001; Guo et al. 2004; Wan et al. 2013; Wang et al. 2015), and oil and gas enrichment (Mi et al. 2010; Sun et al.2019). However, the coal accumulation in relation to the sequence stratigraphy in Songliao Basin continental rift basins are still not well understood, with previous studies being limited to a range of several faulted sags or sub-basins, or only from the perspective of lithological association analysis (Shao et al. 2017).

In this study, based on analyses of facies and facies associations, the sequence stratigraphic framework of the Early Cretaceous coal-bearing series in the Yingcheng, Changchun and Liufangzi sub-basins along the southeastern margin of Songliao Basin in Jilin Province is established, and the distribution patterns of thick coal seams and the main controlling factors of a sequence framework in these rift sub-basins are discussed.

\section{Geological setting}

Songliao Basin can be divided into 6 structural units, including northern uplift, northeastern plunge, western slope, central depression, southwestern uplift, and southeastern uplift (Fig. 1). The study area is on the southeastern uplift of Songliao Basin in Jilin Province, which includes Yingcheng, Changchun and Liufangzi sub-basins. The formation of Songliao Basin has experienced the Early Cretaceous synrift stage, Early to Late Cretaceous postrift stage and a Cenozoic stage of structural basin inversion ( $\mathrm{Li}$ 1988; Shao et al. 2013; Wang et al. 2016). The most important coal accumulation occurred in the synrift stage.

Coal-bearing deposits were formed in the Early Cretaceous synrift basin. The synrifting stage can be further divided into 3 stages including the initial rifting stage (Huoshiling Formation), strong downfaulting stage (Shahezi Formation) and shrinkage stage (Yingcheng Formation) from base to top (Mi et al. 2010).

The Early Cretaceous strata overlie unconformably on the Paleozoic rocks and they are conformably or unconformably overlain by the Denglouku Formation of the Early Cretaceous. Shahezi Formations is the main coalbearing series in the area. All these formations are composed of siliciclastic rocks, intercalated with volcanic rocks or volcaniclastic rocks.

Huoshiling Formation: this formation is distributed in the Taojiagou, Yangcaogou and Yingcheng areas. There are 3 lithological members:member I is the lower volcanic rock member, member II in the middle is composed of terrigenous clastic rocks, and member III is the upper volcaniclastic rock member, most of which is intermediate and basic rocks. During the volcanic eruption intermission, the alluvial fan sediments deposited in the area far away 


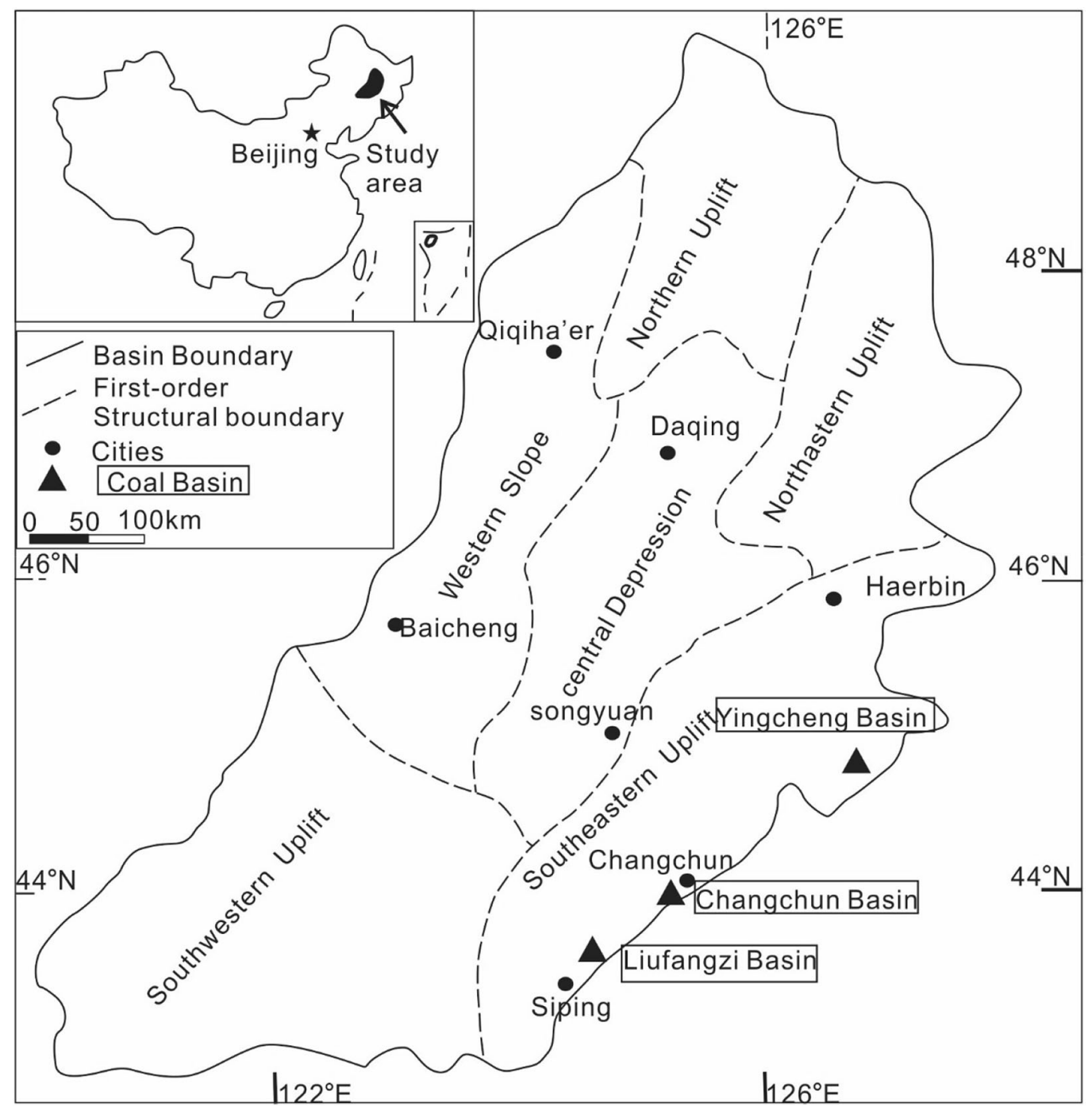

Fig. 1 Sketch map showing structural units and coal basins location of Songliao Basin ( modified according to Wang et al. 2007 and Feng et al. 2013b)

from the volcano. The total thickness of this formation is 450-580 m.

Shahezi Formaiton: this formation is distributed in the whole Songliao Basin. The strata can be subdivided into 2 members according to their lithology. Member I is represented by the bottom conglomerate unit, middle coal-bed unit, upper sandstone and mudstone units. Member II is represented by conglomerate-sandstone unit, mudstone and coal-bed unit and conglomerate unit from base to top. The sedimentary facies in Shahezi Formaiton include alluvial river, fluvial fan, delta and lacustrine facies. The total thickness of this formation is $350-690 \mathrm{~m}$.

Yingcheng Formation: this formation is distributed in Siping, Taojiatun, Dadingzi, Yangcaogou and Yingcheng areas. The lithological units of this formation can be subdivided into 3 members, the bottom pyroclastic rocks member (member I), lower coal-bearing member (member
II), upper pyroclastic rock member (member III) and top sandstone-conglomerate member (member IV). Several layers of volcanic rocks can also be found, with basal part of this formation being gray or green tuffaceous sandstone. The thickness of this formation is about 60-700 $\mathrm{m}$ (Fig. 2).

\section{Sequence stratigraphy analysis}

\subsection{Key sequence stratigraphic boundaries}

The foundation of the sequence stratigraphy mainly depends on recognition of the key sequence stratigraphic boundaries and analysis of the vertical and lateral distribution of the lithofacies associations. The key boundaries include the sequence boundary, initial flooding surface and maximum flooding surface. 


\subsubsection{Sequence boundary}

In the research area, the sequence boundary can be represented by the regional unconformity, basal erosional surfaces of incised valley fills and the abrupt depositional facies-reversal surface (Vail et al. 1977; Mitchum et al. 1977; Posamentier and Vail 1988; Van Wagoner et al. 1990).

(1) Regional unconformity. the unconformable surface is an ideal sequence boundary which represents a long term exposure of the basement. The base of the Huoshiling Formation is a regional unconformity which is underlain by the Palaeozoic strata. The unconformity is widespread and correlatable in a large area and constitutes a good sequence boundary.

(2) Erosional base of incised valley fills. the thick-bedded conglomerates and sandstones tend to have an obvious erosional base, and they represent incised channel deposits. These erosional bases can be regarded as sequence boundaries formed during low base level. In the research area, the conglomerates and sandstones develop well at the bottom of member I and member II of the Shahezi Formation, and the basal surfaces of these conglomerates and sandstones represent regional sequence boundaries (Fig. 2). At the bottom of the Yingcheng Formation, the conglomerate is associated with the volcanic rocks, and the base of this association is also regarded as a sequence boundary (Sun et al. 2019; Wan et al. 2013).

(3) Reversal surface of vertical facies. Sequence boundary is usually associated with the exposure events in the updip area of the basin, but in the downdip area of the basin and inter-fluvial zone of the updip area, the incised channels do not develop very well and a relatively conformable surface could develop at the corresponding horizon. In this case, a shallowing upward (commonly showing coarsening upward) succession will turn to a deepening upward (commonly showing fining upward) succession, and the surface separating these 2 successions is correlatable with the unconformity in the updip area of the basin. The surface between member I and member II of Shahezi Formation in Yingcheng sub-basin has been interpreted as this type of the sequence boundary (Fig. 3 at No.7150 borehole).

\subsubsection{Transgressive surface and maximum flooding surface}

Lacustrine transgressive surface is the surface formed when lake water floods acrossed a slope break or the lowstand incised valley for the first time. In the study area, the bottom boundary of fine-grained rock such as mudstone, silty mudstone, and siltstone that lies immediately above the incised valley filled with sandy conglomerates is regarded as the transgressive surface. This surface is coincident with the sequence boundary in the inter-fluvial area where no channel sandstones or conglomerates are developed. The bottom of the lower coal-bearing of member I in Shahezi Formation is a transgressive surface in the research area (Fig. 3 No.7816, 7820 borehole).

The maximum flooding surface ( $\mathrm{mfs}$ ) is a depositional surface formed at the maximum rates in base level rise when the rates in the creation of accommodation space largely outpaced the rates in sediment supply. In a sequence, when some fine-grained lithologies present as relatively greater-thickness, their bottom can be regarded as the maximum flooding surface. When a series of the darkest lithofacies horizons representing deepest environments repeats in the vertical section only the bottom of the thickest horizon can be taken as the maximum transgressive surface. In the research area, the thick-bedded mudstone at the bottom of the upper sandstone and mudstone segment in member II of the Shahezi Formation is a maximum flooding surface (Fig. 3. No.13-3 borehole in Liufangzi sub-basin).

\subsection{Sequence stratigraphic framework}

Based on recognition of the key sequence stratigraphic surface, six sequence boundaries are recognized, including the unconformity beneath the Huoshiling, Shahezi, Yingcheng, Denglouku Formations, and the bases of incised valley fill conglomerates in the Shahezi Formation.

The Early Cretaceous successions can be subdivided into 5 sequences by these sequence boundaries. The Huoshiling, Shahezi, and Yingcheng formations of Early Cretaceous strata are correlated with the stages from Berriasian to Barremian (Wang et al. 2013), spaning from 245 to 125 million years ago, and lasting for 20 million years (Cohen et al. 2013). Assuming the several tens of million years hiatus during unconformity-based boundaries, each of these sequences represent roughly less than 4 million years and have fallen into the third-order sequence realms of (Vail et al. 1977).

\subsubsection{Sequence I}

The representation of sequence I is Huoshiling Formation which has incomplete lithology information and only manifests a suite of volcanic rocks alternated with alluvial fan conglomerates. This sequence, with a regional basal unconformity, can be subdivided into lowstand systems tract (LST), transgressive systems tract (TST), highstand systems tract (HST) in the Yingcheng sub-basin and Changchun sub-basin, and thin coal seams can be found in the TST of the volcaniclastic rocks member in Yingcheng sub-basin. 


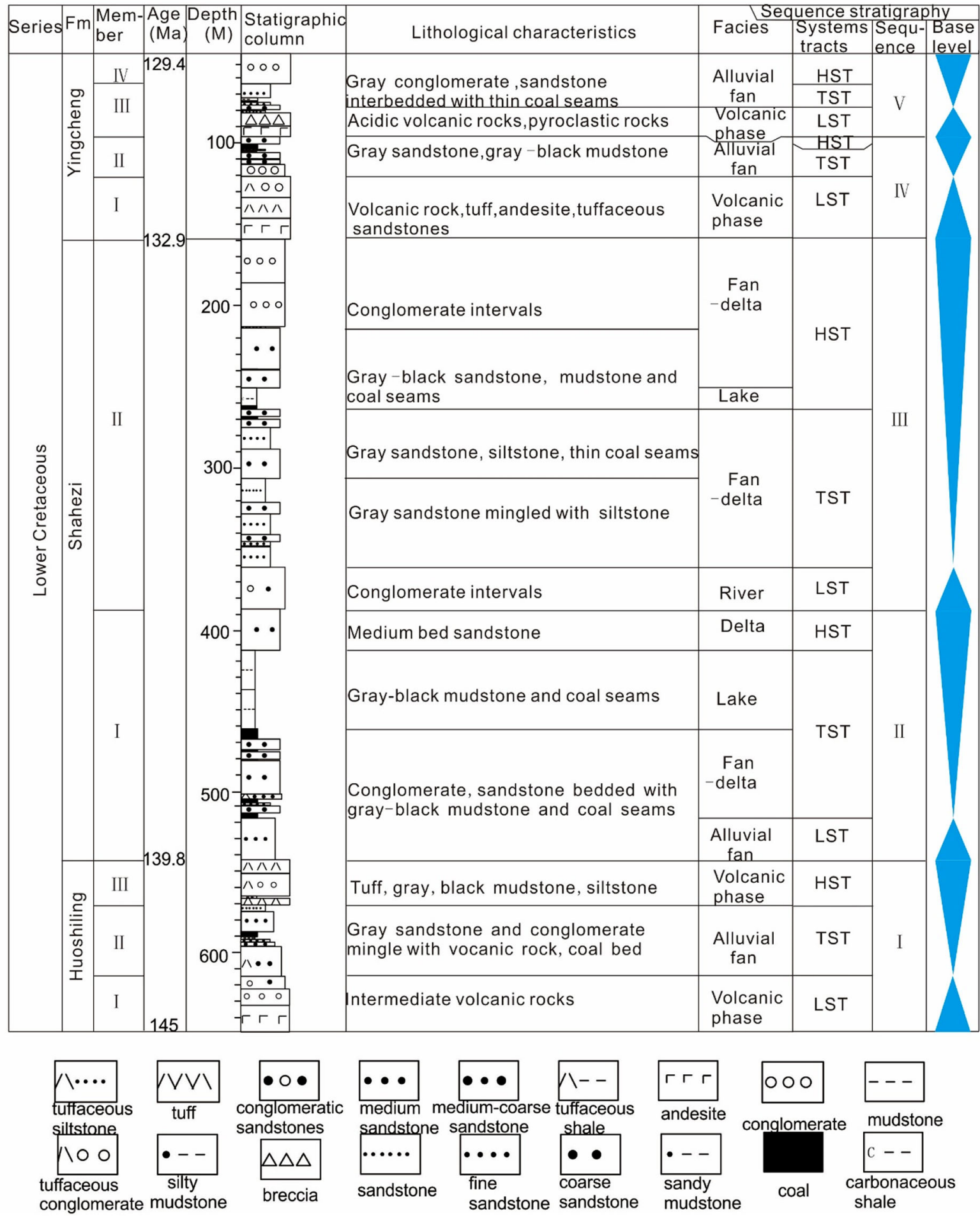

Fig. 2 Cross sections showing sequence stratigraphic framework of the Early Cretaceous coal-bearing strata in the east margin of Songliao Basin

\subsubsection{Sequence II}

Sequence II corresponds to member I of Shahezi Formation in the research area which represents the early phase of stable subsiding stage in the area. The bottom conglomerate member, middle coal-bearing member, upper sandstone and mudstone member which compose the lithological members are corresponding with the LST, TST and HST, respectively. 


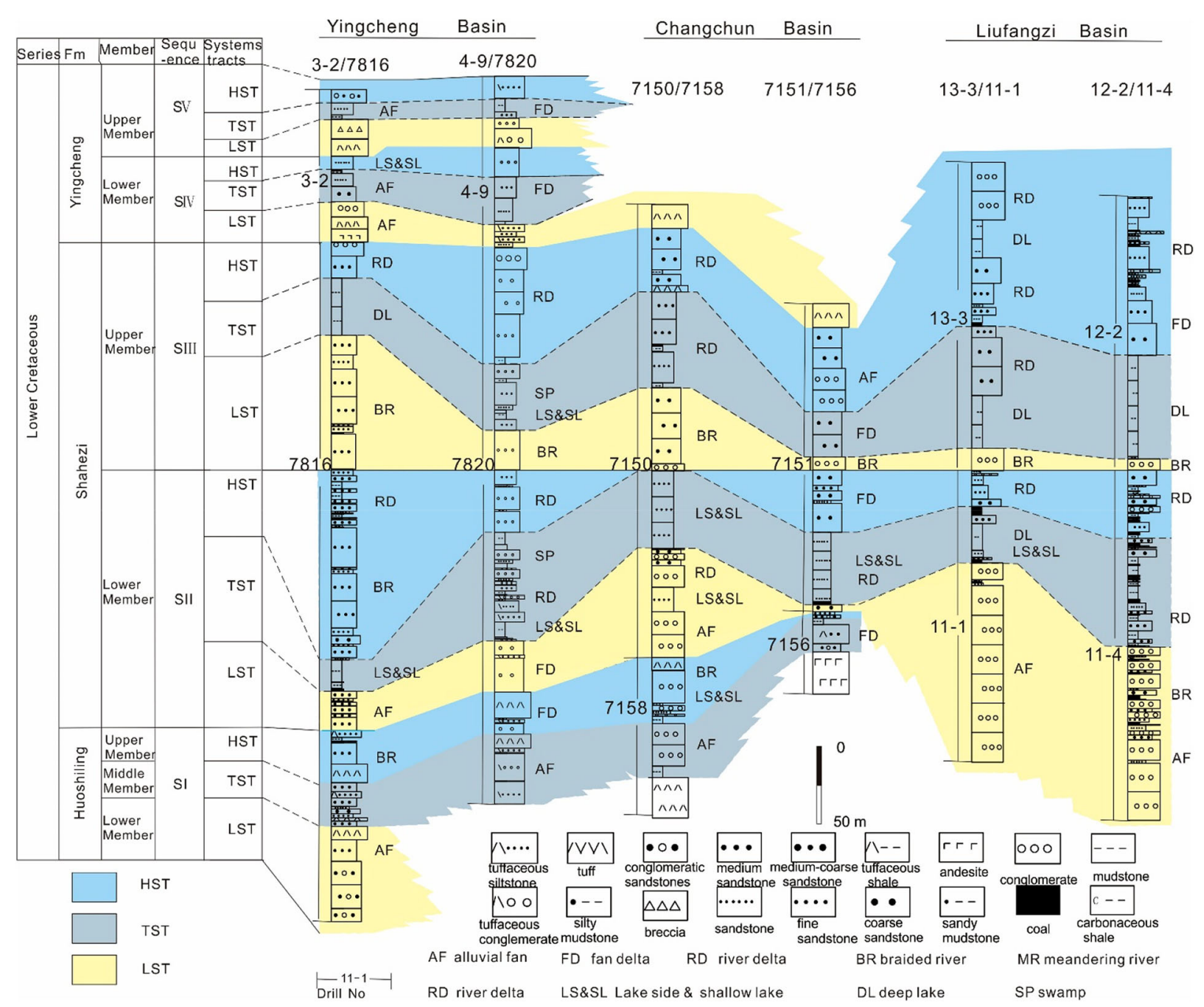

Fig. 3 Integrated columnar section showing sedimentary facies and sequence stratigraphy of the Early Cretaceous coal-bearing series in the southeastern margin of Songliao Basin

The bottom conglomerate member is dominated by alluvial fan facies, represented by the matrix-supported conglomerates and clast-supported conglomerates, with the latter being developed with trough cross beddings. The erosional base developed in conglomerates which represents the sequence boundary, while the whole conglomerate member represents the LST of this sequence. Coal seams can be found in the middle coal-bearing unit of the TST which is dominated by sandy mudstone, siltstone, mudstones, and several cyclical sandstone-mudstone successions. The thick coal seams intercalated with thin mudstones deposited in delta plain swamp environments during this period. The upper sandstone and conglomerate member of the HST is dominated by an intercalation of sandstones and conglomerate. A thick succession of siltstone and mudstone can be found in the middle to upper parts of this member, which represented the shallow lacustrine facies during the flooding period of the early
HST. The overlying sandstone and mudstone interbedding shows an upward coarsening succession, which represented a later HST.

The TST is the best period for the coal formation in every basin, while there are still some minable coal seams in HST of the Liufangzi sub-basin and Yingcheng subbasin in the meandering river delta.

\subsubsection{Sequence III}

Sequence III corresponds to member II of the Shahezi Formation in the research area during the late phase of further downfaulting stage in the area. Unlike sequence II, tectonic movements in sequence III were weaker, so the lithology in this sequence was finer, especially in Yingcheng and Liufangzi sub-basins. The base of the sequence is represented by the basal erosional surfaces of incised valley fills, and local unconformity is recognized in the 
area. This sequence can be subdivided into the LST, TST and HST, which correspond to the bottom conglomeratesandstone member, middle coal-bearing member, upper sandstone, mudstone and conglomerate member.

In sequence III, the LST is dominated by a series of gray sandstones or conglomerates which were deposited in braided fluvial environments. The TST is dominated by sandstone and mudstone interbedding, showing an upward fining sequence variation from delta plain facies to delta front and shallow lacustrine facies. The HST is represented by another sandstone and conglomerate interbedding, showing an upward coarsening sequence. In each basin, the upper part of the TST and lower part of HST are dominated by the facies variation of delta front, delta plain to braided fluvial. The delta plain was developed in the late TST and early HST and the upper coal seams were formed. In Yingcheng sub-basin and Changchun sub-basin, the upper coal seams were less developed than that in sequence II.

\subsubsection{Sequence IV}

Sequence IV corresponds to bottom volcanic rocks member and lower coal-bearing member in Yingcheng Formation in the research area. The lithology is a suite of volcanic-terrigenous siliciclastic rocks, and volcanic rocks are intermediate and basic rocks. The base of the sequence is represented by a regional unconformable boundary between sequence IV and sequence $\mathrm{V}$, which can be recognized in the seismic section (Guo et al. 2004). The clastic rock and thin coal seams deposit in sequence IV in the area which is far from the volcano in TST or HST in the alluvial fan environement of the Yingcheng sub-basin. In Changchun sub-basin, the lithology is mainly tuff rocks. In Liufangzi sub-basin, sequence IV has not been found.

\subsubsection{Sequence $V$}

Sequence $\mathrm{V}$ corresponding to upper volcanic rocks member and top sandstone-conglomerate member can only be found in Yingcheng sub-basin. The thin coal seams formed in the alluvial fan environments of sequence $\mathrm{V}$ are similar to those in the Sequence IV alluvial fan.

\section{Coal accumulation model in the sequence stratigraphic framework}

Coal accumulation models and depositional models of continental basins in the sequence stratigraphic framework have been widely discussed (Bohacs and Suter 1997; Shao et al. 2011; Li et al. 2018b; Wang et al. 2020). Olsen (1990) developed three lacustrine depositional models based on observations from the Triassic fault basins of the
North American Atlantic continental margin: Richmondtype, Newark-type, and Fundy-type. The Richmond-type is characterized by significant coals and highly bioturbated shallow-water and fluvial sequences. The Newark-type is characterized by many Van Houten cycles, extreme lateral continuity, and a tendency for coarse-grained sediment to be absent from deeper water facies and is restricted to the basin margins. The Fundy type is characterized by sandpatch cycles, evaporites, and eolian dunes. Carroll and Bohacs (1999) improved the definition of three ancient lake types, based on the relative balance between rates of potential accommodation (mostly tectonic) and sediment + water supply (mostly climatic). Based on sequence stratigraphic, paleogeographic and coal accumulation analysis, combined with Olsen (1990), and Carroll and Bohacs (1999), the coal-accumulation model is summarized for the southern Sonliao Basin (Fig. 4).

Based on the data collected in the study area, the distribution of coal seams in Early Cretaceous sequence stratigraphic framework has been studied. The thickness of coal seams from sequence I to sequence IV is: $0.13 \mathrm{~m}$, $3.1 \mathrm{~m}, 2.53 \mathrm{~m}, 0.195 \mathrm{~m}$ and $0.13 \mathrm{~m}$ (Table 1). It shows that sequence II is the best coal accumulation period in the study area, sequence III is the second best, while sequence I is the worst.

In general, coal accumulation was affected by the tectonic movements in the study area, and sequence IV and V developed during the basin shrinking stage. During sequence I, sequence IV and sequence $\mathrm{V}$, tectonic and volcanic activities were intense in this area, so coal seams were not easy to form. Sequence I developed at the initial subsiding stage, and sequence II and sequence III developed during the stable subsiding stage. During sequence II and sequence III the relative balance between the expanding rate of accommodation space and the peat accumulating rate favored the formation of the regionally thick coal seams. These 2 sequences correspond to the lower coal seams and the upper coal seams respectively.

In sequence II, coal seams can be found in the middle coal-bearing unit of the TST which is dominated by sandy mudstone, siltstone, mudstones, and several cyclical sandstone-mudstone successions. The thick coal seams intercalated with thin mudstones were deposited in delta plain swamp environments. In sequence II, the thick coals were formed in the delta plain environments which were developed in the late TST and early HST. These characteristics suggest a transformation stage from a Newark-type to Richmond-type basin, which also makes a transitional stage between an overfilled and balanced-filled lake basins (Olsen 1990; Carroll and Bohacs 1999).

In overall, during the initial subsiding stage and stable subsiding stage, with the tectonic movements background, the coal seams formed in the LST, TST and 


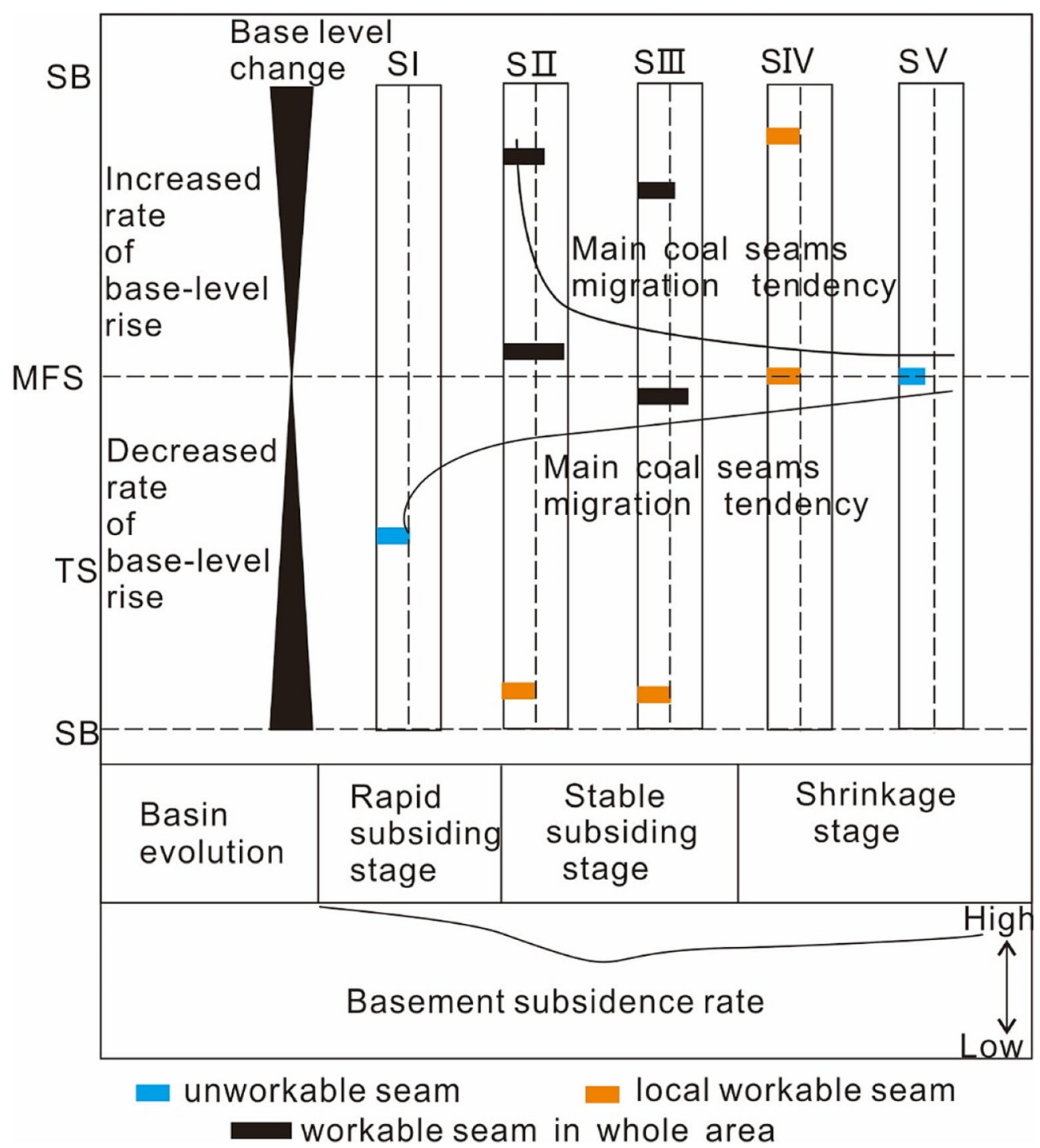

Fig. 4 The distribution of main coal seams in the sequence stratigraphic framework of the study area

later stage of the HST. Then the tectonic movements made the basin basement subsidence rate become higher. In the stable subsiding stage, the rate of the basement subsidence and accommodation space expansion changed slowly and then the main coal seams deposited near the area of the maximum flooding surface (Fig. 4).

\section{Conclusions}

(1) Based on recognition of the key sequence stratigraphic surface, basal erosional surfaces of incised valley fills, abrupt depositional facies-reversal surface in the research area, the coal-bearing series can be subdivided into 5 third-order sequences by 6 sequence boundaries. Sequence I corresponds to Huoshiling Formation, sequence II and III correspond to member I and member II in Shahezi Formation. Sequence IV and V correspond to member I and member II in Yingcheng Formation.

(2) Coal accumulation and stratigraphic sequence was affected by the tectonic movements in the southeastern margin of Songliao Basin in the Early Cretaceous. From sequence I to V, the coal accumulation changed from the LST, TST and late HST to the horizons around the maximum flooding surface. The best periods for coal accumulation are sequence II and III, in which the relative balance between the increase rate of accommodation space and the peat accumulating rate favors the formation of the regionally thick coal seams, forming regional lower coal seams and upper coal seams respectively. 
Table 1 Distribution of coal seams in the Early Cretaceous sequence stratigraphic framework of Songliao Basin

\begin{tabular}{|c|c|c|c|c|c|c|}
\hline \multirow[t]{2}{*}{ Formation } & \multirow[t]{2}{*}{ Sequence } & \multirow[t]{2}{*}{ System tracts } & \multicolumn{3}{|l|}{ Coal seam thickness } & \multirow[t]{2}{*}{ Average thickness } \\
\hline & & & Yingcheng sub-basin & Changchun sub-basin & Liufangzi sub-basin & \\
\hline \multirow[t]{6}{*}{ Yingcheng Fm } & \multirow[t]{3}{*}{$\mathrm{V}$} & HST & 0 & & & 0 \\
\hline & & TST & 0.13 & & & 0.13 \\
\hline & & LST & 0 & & & 0 \\
\hline & \multirow[t]{3}{*}{ IV } & HST & 0.1 & 0 & & 0.1 \\
\hline & & TST & 0.13 & 0.06 & & 0.095 \\
\hline & & LST & 0 & 0 & & 0 \\
\hline \multirow{6}{*}{ Shahezi Fm } & \multirow[t]{3}{*}{ III } & HST & 0.7 & 1.12 & 1.15 & 0.99 \\
\hline & & TST & 0.85 & 0.56 & 1.90 & 1.10 \\
\hline & & LST & 0.3 & 0.4 & 0.61 & 0.44 \\
\hline & \multirow[t]{3}{*}{ II } & HST & 1.3 & 0.7 & 1.24 & 1.08 \\
\hline & & TST & 1.55 & 1.36 & 1.57 & 1.49 \\
\hline & & LST & 0.23 & 0.3 & 1.05 & 0.53 \\
\hline \multirow[t]{3}{*}{ Huoshiling Fm } & \multirow[t]{3}{*}{ I } & HST & 0.03 & 0 & & 0.03 \\
\hline & & TST & 0.1 & 0 & & 0.1 \\
\hline & & LST & 0 & 0 & & 0 \\
\hline
\end{tabular}

Acknowledgements This research is supported by the National Science and Technology Major Project (2016ZX05041004-003), the National Natural Science Foundation of China (41572090), Fundamental Research Funds for Central Universities of China University of Mining and Technology (Beijing), and Yue Qi Scholar Project of China University of Mining and Technology (Beijing).

Open Access This article is licensed under a Creative Commons Attribution 4.0 International License, which permits use, sharing, adaptation, distribution and reproduction in any medium or format, as long as you give appropriate credit to the original author(s) and the source, provide a link to the Creative Commons licence, and indicate if changes were made. The images or other third party material in this article are included in the article's Creative Commons licence, unless indicated otherwise in a credit line to the material. If material is not included in the article's Creative Commons licence and your intended use is not permitted by statutory regulation or exceeds the permitted use, you will need to obtain permission directly from the copyright holder. To view a copy of this licence, visit http://creativecommons. org/licenses/by/4.0/.

\section{References}

Bohacs KM, Suter J (1997) Sequence stratigraphic distribution of coaly rocks: fundamental controls and paralic examples. AAPG Bull 81(3):1612-1639

Carroll AR, Bohacs KM (1999) Stratigraphic classification of ancient lakes: balancing tectonic and climatic controls. Geology 27(2):99-102

Catuneanu O, Abreu V, Bhattacharya JP, Blum MD, Dalrymple RW, Eriksson PG et al (2009) Towards the standardization of sequence stratigraphy. Earth-Sci Rev 92(1-2):1-33

Cohen KM, Finney SC, Gibbard PL, Fan JX (2013) The ICS international chronostratigraphic chart. Episodes 36: 199-204.

Diessel CFK (1992) Coal-bearing depositional systems. Springer, Berlin, Heidelberg, pp 1-721
Diessel CFK (2007) Utility of coal petrology for sequence stratigraphic analysis. Int J Coal Geol 70(1-3):3-34

Feng YL, Li ST, Lu YC (2013a) Sequence stratigraphy and architectural variability in Late Eocene lacustrine strata of the Dongying Depression, Bohai Bay Basin, Eastern China. Sediment Geol 295:1-26

Feng ZQ, Wang CS, Graham S, Koeberl C, Dong HL, Huang YJ, Gao Y (2013b) Continental scientific drilling project of Cretaceous Songliao Basin: scientific objectives and drilling technology. Palaeogeogr Palaeoclimatol Palaeoecol 385:6-16

Fielding CR, Bann KL, Trueman JD (2007) Resolving the architecture of a complex, low-accommodation unit using high-resolution sequence stratigraphy and ichnology: the Late Permian Freitag formation in the Denison Trough, Queensland, Australia. In: MacEachern JA, Bann KL, Gingras MK, Pemberton SG (eds) Applied ichnology, vol 52. SEPM short course notes. Society for Sedimentary Geology, Tulsa, pp 1-30

Flint SS, Aitken J, Hampson G (1995) Application of sequence stratigraphy to coal-bearing coastal plain successions: Implications for the UK coal measures. In: Whateley MKG, Spears DA (eds) European coal geology, vol 82. Geological Society, Special Publications, London, pp 1-16

Gao RQ, Cai XY (1997) Forming-conditions and distribution regularities of the oil fields in Songliao Basin. Petroleum Publishing House, Beijing, pp 1-321. (in Chinese)

Gibling MR, Saunders KI, Tibert NE, White JA (2004) Sequence sets, high-accommodation events, and the coal window in the Carboniferous Sydney Coalfield, Atlantic Canada. In: Pashin JC, Gastaldo RA (eds) Sequence stratigraphy paleoclimate and tectonics of coal bearing strata, vol 51. AAPG Studies in Geology. American Association of Petroleum Geologists, Tulsa, pp 169-197

Guo W, Liu ZJ, Dong HM, Zhao YJ (2004) The sequence stratigraphic features and hydrocarbon accumulation of Songliao Basin. Journal of Jilin University (Earth Science Edition) 2(34):216-222 (in Chinese with English abstract)

Han DX, Yang Q (1980) Coal geology of China, vol 2. Coal Industry Publishing House, Beijing, pp 1-415 (in Chinese) 
Holz M, Kalkreuth W, Banerjee I (2002) Sequence stratigraphy of paralic coal-bearing strata: an overview. Int $\mathbf{J}$ of Coal Geol 48(3-4):147-179

Hu SQ, Guo WP, Yang FG, Yan QB, Liu SG, Tong CG (2001) Study on influential factors of terrigenous sequence formation and development in fault-depressed lacustrine basin. Acta Sedimentol Sin 19:256-262

Jerrett RM, Flint SS, Davies RC, Hodgson DM (2011) Sequence stratigraphic interpretation of a Pennsylvanian (upper carboniferous) coal from the central Appalachian Basin, USA. Sedimentology 58(5):1180-1207

Li ST (1988) Fault Basin Analysis and Coal accumulation: An Approach to Sedimentation, Tectonic evolution, and Energy Resource Prediction in the Late Mesozoic Fault Basins of Northeastern China. Geological Publishing House, Beijing, pp 1-367 (in Chinese)

Li Z, Wang D, Lv D, Li Y, Liu H, Wang P, Liu Y, Liu J, Li D (2018a) The geologic settings of Chinese coal deposits. Int Geol Rev 60:548-578

Li YN, Shao LY, Hou H, Tang Y, Yuan Y, Zhang J, Shang X, Lu J (2018b) Sequence stratigraphy, palaeogeography, and coal accumulation of the fluvio-lacustrine Middle Jurassic Xishanyao Formation in central segment of southern Junggar Basin, NW China. Int J Coal Geol 192:14-38

Lin C, Eriksson K, Li S, Wan Y, Ren J, Zhang Y (2001) Sequence architecture, depositional systems, and controls on development of lacustrine basin fills in part of the Erlian Basin, Northeast China. AAPG Bull 85(11):2017-2043

Liu H, Chi XY, Li W (2011) Tectono-paleogeographic study of the Early Cretaceous in the Songliao Basin. Min Sci Technol (China) 11:93-98

Martins-Neto MA, Catuneanu O (2010) Rift sequence stratigraphy. Mar Petrol Geol 27(1):247-253

Mi JK, Zhang SC, Hu GY, He K (2010) Geochemistry of source rocks and natural gases in deep formations in Songliao Basin, NE China. Int J Coal Geol 84:276-285

Mitchum RM Jr, Vail PR, Thompson S (1977) III Seismic stratigraphy and global changes of sea level: part 2. The depositional sequence as a basic unit for stratigraphic analysis. In: Payton CE (ed) Seismic stratigraphy-applications to hydrocarbon exploration, vol 26. AAPG Memoir. American Association of Petroleum Geologists, Tulsa, pp 53-62

Olsen PE (1990) Tectonic climatic, and biotic modulation of lacustrine ecosystems-examples from Newark Supergroup of Eastern North America. In: Katz B (ed) Lacustrine basin exploration: case studies and modern analogs, vol 50. AAPG Memoir. American Association of Petroleum Geologists, Tulsa, pp 209-224

Posamentier HW, Vail PR (1988) Eustatic controls on clastic deposition II-sequence and systems tract models. In: Wilgus CK, Hastings BS, Posamentier HW, Van Wagoner JC, Ross CA, Kendall CGStC (eds) Sea-level changes: an integrated approach, vol 42. SEPM Special Publication, Tulsa, pp 125-154

Ravnas R, Steel RJ (1998) Architecture of marine rift-basin successions. AAPG Bull 82(1):110-146

Shanley KW, McCabe PJ (1994) Perspectives on the sequence stratigraphy of continental strata. AAPG Bull 78(4):544-568

Shao LY, Zhang PF, Hilton J, Gayer R, Wang YB, Zhao CY, Luo Z (2003) Paleoenvironments and paleogeography of the Lower and lower Middle Jurassic coal measures in the Turpan-Hami oilprone coal basin, northwestern China. AAPG Bull $87(2): 335-355$

Shao LY, Lu J, Wei KM, Su SC (2011) Depositional environments and resource prediction of the late triassic coal measures in baoding basin of the Panzhihua Area, Sichuan Province. Geological Publishing House, Beijing, pp 1-213 (in Chinese)
Shao K, Shao LY, Qu YL, Zhang Q, Wang J, Gao D, Wang DD, Li Z (2013) Study of sequence stratigraphy of the Early Cretaceous coal measures in northeastern China. J China Coal Soc 38(S2):423-433 (in Chinese with English abstract)

Shao LY, Dong DX, Li MP, Wang HS, Wang DD, Lu J, Zheng MQ, Cheng AG (2014) Sequence-Paleogeography and coal accumulation of Carboniferous-Permian in the North China Basin. Journal of China Coal Society 39:1725-1734 (in Chinese with English abstract)

Shao LY, Wang XT, Lu J, Wang DD, Hou HH (2017) A reappraisal on development and prospect of coal and sedimentary in China. Acta Sedimentary Sinica 35:1016-1031 (in Chinese with English abstract)

Strecker U, Steidtmann JR, Smithson SB (1999) A conceptual tectonostratigraphic model for seismic facies migration in a fluvio-lacustrine extensional basin. AAPG Bull 83(1):43-61

Sun Y, Liu RH, Yu LM, Yan BQ, Wen HJ, Sun Y (2019) Accumulation characteristics, controlling factors and migration of tights and stone oil below source rocks: a case study of Fuyu reservoirs of the Cretaceous Quantou Formation in Da'an area of Songliao. Journal of China University of Mining \& Technology 48:793-805

Vail PR, Mitchum RM, Thompson S (1977) III. Seismic stratigraphy and global changes of sea level: part3. Relative changes of sea level from coastal onlap, in Payton CE, ed., Seismic stratigraphy-Applications to hydrocarbon exploration. AAPG Memoir 26:63-81

Van Wagoner JC, Mitchum RM, Campion KM, Rahmanian VD (1990) Siliciclastic sequence stratigraphy in well, cores and outcrop-concept for high resolution correlation of times and facies. AAPG Methods in Exploration Series 7:1-55

Wan XQ, Zhao J, Scott RW, Wang PJ, Feng ZJ, Huang QJ, Xia DJ (2013) Late Cretaceous stratigraphy, Songliao Basin, NE China: SKI cores. Palaeogeogr Palaeocl 385:31-43

Wang GL, Ju YW, Zheng ML, Cao DY, Qin Y, Zhu YM (2007) Tectonics of energy resource Basins in the Northern China. China University of Mining and Technology Press, Xuzhou, pp 1-541 (in Chinese)

Wang JQ, Yang G, Xue LF, Zhang JW, Bai Y, Li WB (2011) Tectonic evolution of the Changling fault basin and its relationship to oil and gas accumulation. Mining Sci Technol (China) 21:427-432

Wang CS, Feng ZQ, Zhang LM, Huang YJ, Cao K, Wang PJ, Zhao B (2013) Cretaceous paleogeography and paleoclimate and the setting of SKI borehole sites in Songliao Basin, northeast China. Palaeogeogr Palaeocl Palaeoecol 385:17-30

Wang HY, Fan TL, Wu Y (2015) The subsurface structure and stratigraphic architecture of rift-related units in the Lishu Depression of the Songliao Basin. China. J Asian Earth Sci 99(1):13-29

Wang PJ, Mattern F, Didenko NA, Zhu DF, Singer B, Sun XM (2016) Tectonics and cycle system of the Cretaceous Songliao Basin: an inverted active continental margin basin. Earth-Sci Rev 159:82-102

Wang S, Shao LY, Wang DD, Sun QP, Sun B, Lu J (2019) Sequence stratigraphy and coal accumulation of Lower Cretaceous coalbearing series in Erlian Basin, northeastern China. AAPG Bull 103(7):1653-1690

Wang S, Shao LY, Wang DD, Hilton J, Guo B, Lu J (2020) Controls on accumulation of anomalously thick coals: implications for sequence stratigraphic analysis. Sedimentology 67:991-1013

Zecchin M, Mellere D, Roda C (2006) Sequence stratigraphy and architectural variability in growth fault bounded basin fills: a review of Plio-Pleistocene stratal units of Croton basin, southern Italy. J Geol Soc London 163(3):471-486 